\title{
IDENTIFIKASI GEJALA CHILLING INJURY BERDASARKAN PERUBAHAN pH DAN ION LEAKAGE PADA BUAH MANGGA GEDONG GINCU
}

\author{
Putri Wulandari Zainal ${ }^{1}$, Aris Y Purwanto ${ }^{2}$, dan Usman Ahmad ${ }^{2}$ \\ ${ }^{1}$ Jurusan Teknik Pertanian, Fakultas Teknologi Pertanian, Universitas Andalas \\ ${ }^{2}$ Departmen Teknik Mesin dan Biosistem, Fakultas Teknologi Pertanian, Institute Petanian Bogor \\ E-mail:putriwulandariz87@gmail.com
}

\begin{abstract}
ABSTRAK
Mangga Gedong Gincu merupakan buah tropika yang disukai oleh masyarakat.Buah tropika dan sub-tropika sensitif dengan paparan suhu rendah. Paparan suhu rendah tersebut dapat mengakibatkan terjadinya chilling injury (CI). Adapun gejala CI adalah adanya lekukan, bercak coklat pada permukaan, gagal matang, ion leakage. Tujuan penelitian adalah untuk dapat mengidentifikasi gejala CI yang terjadi selama penyimpanan buah mangga gedong gincu berdasarkan perubahan $\mathrm{pH}$ dan ion leakage. Berdasarkan hasil penelitian buah mangga yang disimpan pada suhu $8^{\circ} \mathrm{C}$, mengalami perubahan $\mathrm{pH}$ yang tidak mencapai 4.5 yaitu dari awal penyimpanan 3.02 menjadi 3.37 pada akhir penyimpanan. Sedangkan untuk penyimpanan suhu $13{ }^{\circ} \mathrm{C}$ mengalami perubahan $\mathrm{pH}$ yang mencapai 4.5 yaitu 3.05 menjadi 4.69, secara normal perubahan $\mathrm{pH}$ buah mangga pada tingkat matang yaitu $2.0 \mathrm{ke}$ $5.5 \mathrm{Hal}$ ini terlihat bahwa buah mangga yang disimpan pada suhu $8^{\circ} \mathrm{C}$ telah mengalami gejala CI yaitu gagal matang. Perubahan ion leakage yang terbesar untuk penyimpanan $8{ }^{\circ} \mathrm{C}$ terjadi pada hari penyimpanan ke-4 dan hari ke-6 untuk penyimpanan $13^{\circ} \mathrm{C}$. Untuk buah mangga yang disimpan pada suhu $8{ }^{\circ} \mathrm{C}$, ion leakage disebabkan oleh adanya stress suhu dingin sehingga membran sel rusak dan menyebabkan kebocoran ion.

Kata kunci- Mangga, Chilling injury, $\mathrm{pH}$, Ion leakege
\end{abstract}

\section{PENDAHULUAN}

Mangga Gedong Gincu merupakan salah satu buah tropik eksotik dari Indonesia yang diimpor oleh semua pasar. Chilling injury adalah masalah utama pada penyimpanan dingin bagi komoditas tropis. Penyimpanan produk dibawah suhu kritis dapat menyebabkan terjadinya gangguan fisiologis yang parah. Suhu kritis untuk chilling injury bervariasi sesuai dengan sifat komoditas, tetapi umumnya terjadi ketika produk disimpan pada suhu dibawah $10^{\circ} \mathrm{C}-13^{\circ} \mathrm{C}$ (Tasneem, 2004). Penyimpanan dingin berfungsi untuk memperpanjang umur simpan buah-buahan, sehingga penyimpanan dingin tidak bisa dihindarkan.

Gejala chilling sering muncul beberapa hari setelah berada di suhu yang lebih hangat dalam bentuk legokan (pitting) atau kulit produk memar, terjadi internal discoloration atau gagal matang. Perkembangan gejala chilling injury sangat dipengaruhi oleh temperatur dan waktu, dimana semakin rendah temperatur gejala akan semakin parah dan semakin lama terpapar suhu rendah gejala juga akan semakin parah (Sayyari, et al., 2011). Pedeteksian bagian internal buah seperti laju respirasi, perubahan $\mathrm{pH}$, persentase kebocoran ion dapat dilakukan untuk mendeteksi gejala CI (Purwanto, et al. 2005). Beberapa jenis mangga akan rusak jika disimpan pada suhu dibawah $9{ }^{\circ} \mathrm{C}$ (Pracaya, 2001). Pada buah mangga, penyimpanan $\leq 13^{\circ} \mathrm{C}$ akan menyebabkan kerusakan dingin (Utama, 2009).

Gejala umum dari chilling injury adalah runtuhnya sel-sel dibawah permukaan kulit yang menyebabkan pitting, pencoklatan enzimatik dan timbulnya seperti genangan air (waterlogging) (Taub, 1998). Gejala kerusakan CI ditunjukkan oleh bintik-bintik hitam dan browning, tingkat kerusakan yang parah yang disebabkan oleh waktu penyimpanan dan disertai oleh pelunakan dan kebocoran ion (electrolyte leakage) (Sayyari, et al., 2011). Perubahan keadaan fisik membran pada suhu dingin juga dianggap bertanggung jawab atas kebocoran peningkatan sel elektrolit dari jaringan yang sensitif temperatur dingin (Paull, 1980). Aktifitas ATPase yang berhubungan dengan $\mathrm{pH}$ dalam penyimpanan buah pepaya dapat dijadikan sebagai penanda biokimia untuk buah klimaterik (Azvedo et al., 2008). Electrolyte leakage dijadkan sebagai parameter gejala CI (Fahmy, 2013; Salveit, 2002). Oubahou (1999) juga melaporkan bahwa buah terong pada penyimpanan $5^{\circ} \mathrm{C}$ mengalami kebocoran ion dan hal ini merupakan salah satu parameter gejala CI. Selain itu, Perubahan ion leakage dan $\mathrm{pH}$ digunakan sebagai indikator terjadinya chilling injury pada mentimun (Purwanto et al., 2012). $\mathrm{Ph}$ dan ion leakage 
merupakan salah satu penyebab terjadinya chilling injury. Oleh karena itu, dilakukan identifikasi gejala $\mathrm{CI}$ berdasarkan perubahan $\mathrm{pH}$ dan ion lekage pada buah mangga gedong gincu, sehingga dapat diketahui perbedaan perubahan mutu yang disebabkan oleh gejala CI selama penyimpanan.

\section{METODOLOGI PENELITIAN}

\section{A. Bahan dan Kondisi Penyimpanan}

Bahan yang digunakan adalah mangga gedong gincu dengan umur panen 90 hari setelah bunga mekar (HSBM) dan indeks kematangan $60 \%$. Mangga gedong gincu yang digunakan adalah tingkat ukuran sedang dengan berat 200-250 gram, berasal dari Indramayu yang dipetik langsung dari petani mangga di Indramayu. Bahan lain yang digunakan adalah teobendazol, aquadest, dan aquabidest.

Bahan yang diuji terlebih dahulu disortasi. Sortasi ini bertujuan untuk memisahkan buah yang cacat dan utuh serta untuk menyeragamkan ukuran. Setelah penyortiran maka buah dicuci dan direndam dalam larutan TBZ $10 \mathrm{ppm}$ selama 1 menit lalu ditiriskan dan dikering anginkan. Pencelupan ini bertujuan untuk mencegah kerusakan buah selama penyimpanan akibat serangga dan mikroorganisme. Kemudian buah dipisahkan kedalam dua kelompok yaitu untuk penyimpanan $8^{\circ} \mathrm{C}$ dan $13^{\circ} \mathrm{C}$, jumlah mangga masing-masing 53 buah untuk masing-masing kelompok pada penelitian tahap pertama dan 10 buah untuk masing-masing kelompok pada penelitian tahap kedua. Setelah buah kering maka buah dikemas kedalam kardus dan dimasukan kedalam cold storage.

\section{B. Prosedur Percobaan \\ 1. Kekerasan}

Pengukuran kekerasan dilakukan dengan menggunakan alat rheometer. Sebelum pengujian buah mangga dengan menggunakan alat rheometer maka terlebih dahulu alat ini distel pada kondisi mode: 20; R/H (hold): 15 mm; P/T (Press): 60 mm/m; Rep. 1: 1x60h; max $2 \mathrm{~kg}$; dengan menggunakan probe nomor 38 (diameter $=2.5 \mathrm{~mm})$.

\section{Total Padatan Terlarut}

Total padatan terlarut diukur dengan menggunakan alat refractometer. Dalam penggunaan alat ini, bahan terlebih dahulu dihaluskan dengan cara ditumbuk. Setelah itu, cairan dari sampel yang telah ditumbuk diletakkan diatas obyek gelas yang terdapat pada alat sehingga total padatan terlarut akan terbaca langsung pada display dalam satuan ${ }^{\circ}$ Brix.

\section{Ion Leakage}

Pengukuran ion leakage telah dilakukan oleh Purwanto et al. dengan modifikasi. Pengukuran ion leakage dilakukan setiap hari pada minggu I dan minggu berikutnya setiap dua hari sekali terhadap sampel selama penyimpanan pada suhu $8{ }^{\circ} \mathrm{C}$ dan $13{ }^{\circ} \mathrm{C}$. Pengukuran dilakukan dengan menggunakan 3 sampel. Ion Leakage diukur berdasarkan perubahan nilai konduktivitas listrik larutan dengan menggunakan Electrical Conductivity Meter (D-2 HORIBA). Dalam pengambilan sampel, daging buah diambil dengan ukuran $1 \times 1 \times 1 \mathrm{~cm}$ kemudian direndam di dalam aquabides $(20 \mathrm{ml})$ yang nilai konduktivitas listrik awalnya diketahui. Pengukuran dilakukan pada suhu ruang dengan selang waktu pengukuran tiap 20, 30, 60 menit selama 4 jam (240 menit). Persamaan yang dapat digunakan untuk mengukur ion leakage dapat dilihat pada Persamaan 18. Dimana $\mathrm{n}_{1}$ merupakan nilai konduktivitas listrik menit ke-0 (awal), $\mathrm{n}_{2}$ merupakan nilai konduktivitas listrik ke- $\mathrm{n}$, dan $\mathrm{n}_{\mathrm{t}}$ merupakan nilai konduktifitas setelah daging buah dihancurkan.

Perubahan ion leakage $=\frac{\left(\mathrm{n}_{2}-\mathrm{n}_{1}\right)}{\left(\mathrm{n}_{\mathrm{t}}-\mathrm{n}_{1}\right)} \times 100 \%$

\section{Perubahan pH}

Pengukuran $\mathrm{pH}$ telah dilakukan oleh Purwanto et al. dan dilakukan beberapa modifikasi. Sampel yang digunakan untuk pengukuran $\mathrm{pH}$, diambil dari tiga titik pengamatan per sampel lalu dihancurkan. Karena buah mangga memiliki daging buah yang tebal dan serat yang banyak maka setelah buah dihancurkan dilakukan pengenceran 1:1. Bahan yang telah dihancurkan akan diukur tingkat keasamannya $(\mathrm{pH})$ dengan menggunakan $\mathrm{pH}$ meter sebanyak tiga kali kemudian nilainya dirataratakan. 


\section{Analisis Data}

Analisis data dilakukan menggunakan rancangan percobaan Rancangan Acak Kelompok (RAK) fakorial menggunakan SPSS 10 pada taraf 5\%.

\section{HASIL DAN PEMBAHASAN}

\section{A. Kekerasan}

Kekerasan buah mangga gedong gincu selama penyimpanan mengalami penurunan. Penurunan ini terjadi seiring dengan lamanya penyimpanan, baik pada buah yang disimpan suhu $8^{\circ} \mathrm{C}$ ataupun suhu $13{ }^{\circ} \mathrm{C}$. Menjadi lunaknya buah disebabkan oleh perombakan protopektin yang tak larut menjadi pektin yang larut atau hidrolisis pati atau lemak (Pantastico, 1989). Pada buah-buahan terdapat dinding sel, dimana senyawa dinding sel terdiri dari atas selulosa, hemiselulosa, pektin, dan lignin (Winarno, 2002). Terjadinya pengempukan buah atau pelunakan buah selama penyimpanan diakibatkan oleh degradasi hemiselulosa dan protopektin.

Proses pelunakan buah selama penyimpanan sangat cepat terjadi pada suhu penyimpanan 13 ${ }^{\circ} \mathrm{C}$ dibandingkan dengan suhu penyimpanan $8{ }^{\circ} \mathrm{C}$ (Gambar 1). Hal ini terjadi karena suhu penyimpanan yang rendah dapat mengurangi laju penurunan kekerasan dimana semakin rendah suhu maka dapat menghambat proses terjadinya metabolisme. Perubahan metabolisme mempengaruhi akan proses respirasi, pematangan, proses penuaan, tekstur, dan warna (Winarno, 2002). Selain itu, Enzim juga memiliki pengaruh dalam terjadinya proses pelunakan (Pantastico, 1989). Dari hasil pengamatan dapat dilihat bahwa kekerasan berkorelasi dengan terjadinya gejala chilling injury, hal ini dapat dilihat dari perubahan kekerasan pada penyimpanan buah mangga suhu $8{ }^{\circ} \mathrm{C}$ yang tetap keras. Suhu penyimpanan yang rendah dalam jangka waktu yang lama ini mengakibatkan metabolisme pada buah mangga tidak berjalan semestinya sehingga menyebabkan tidak terjadinya perombakan pada hemiselulosa dan protopektin.

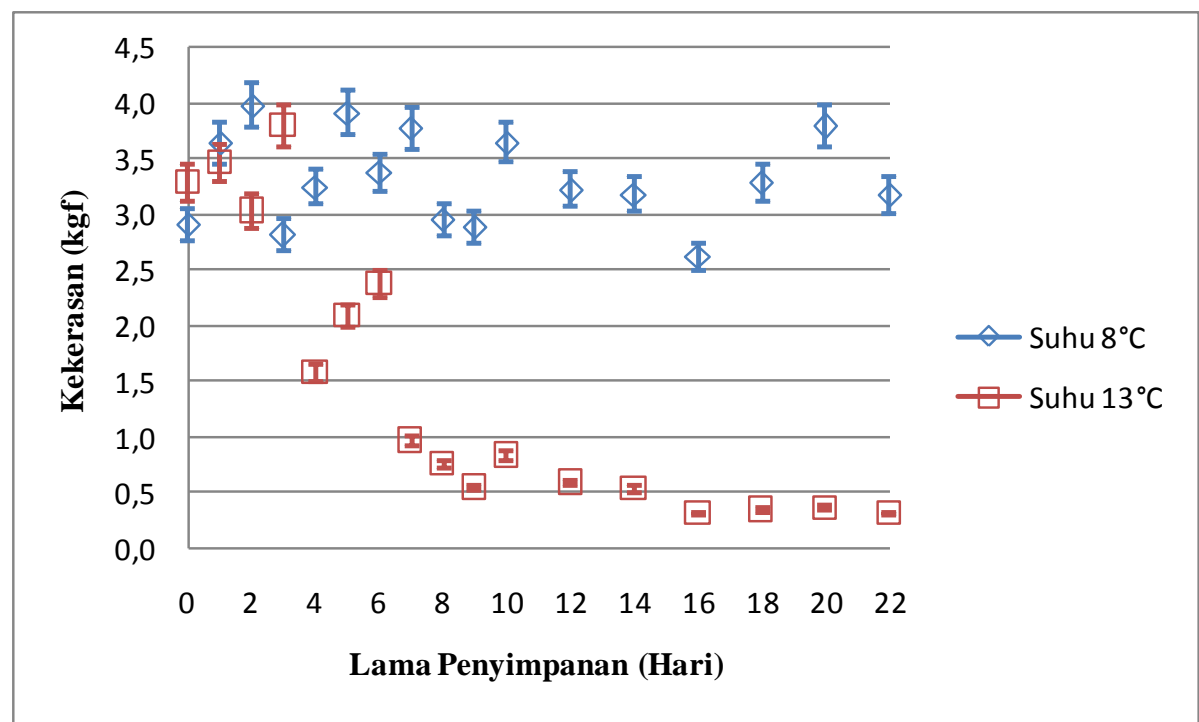

Gambar 1. Perubahan Kekerasan Selama Penyimpanan Dingin

\section{B. Total Padatan Terlarut}

Kandungan gula beberapa jenis buah-buahan klimaterik seperti mangga, kadang akan meningkat selama pendewasaan sel (Muchtadi, 2010). Banyak macam gula yang terdapat pada buahbuahan, akan tetapi perubahan kandungan gula yang sesungguhnya hanya meliputi tiga macam gula yaitu glukosa, fruktosa, dan sukrosa.

Dari hasil pengamatan perubahan total padatan terlarut terlihat bahwa terjadi peningkatan total padatan terlarut selama penyimpanan. Peningkatan total padatan terlarut pada buah mangga selama penyimpanan cukup tinggi yaitu pada hari ke-0 sebesar $10.66^{\circ}$ Brix meningkat menjadi $20,12{ }^{\circ}$ Brix hari ke-22. Akan tetapi peningkatan total padatan terlarut pada penyimpanan buah mangga suhu $8{ }^{\circ} \mathrm{C}$ 
lebih lambat dibandingkan pada buah yang disimpan pada suhu $13{ }^{\circ} \mathrm{C}$ yaitu hari ke-0 $12.4{ }^{\circ}$ Brix menjadi $14{ }^{\circ}$ Brix (Gambar 2). Perubahan total padatan terlarut dipengaruhi oleh suhu dimana suhu semakin rendah maka perubahan total padatan terlarut semakin lambat. Parameter total padatan terlarut ini berkolerasi dengan gejala chilling injury, hal ini dapat dilihat dari terhambatnya proses perombakan pati menjadi glukosa. Secara normal kebanyakan karbohidrat terlarut lainnya mengalami metabolisme selama pematangan buah atau penyimpanan buah serta kegiatan enzim-enzim hidrolitik amilase dapat mengakibatkan hidrolisis zat pati menjadi glukosa (Pantastico, 1989).

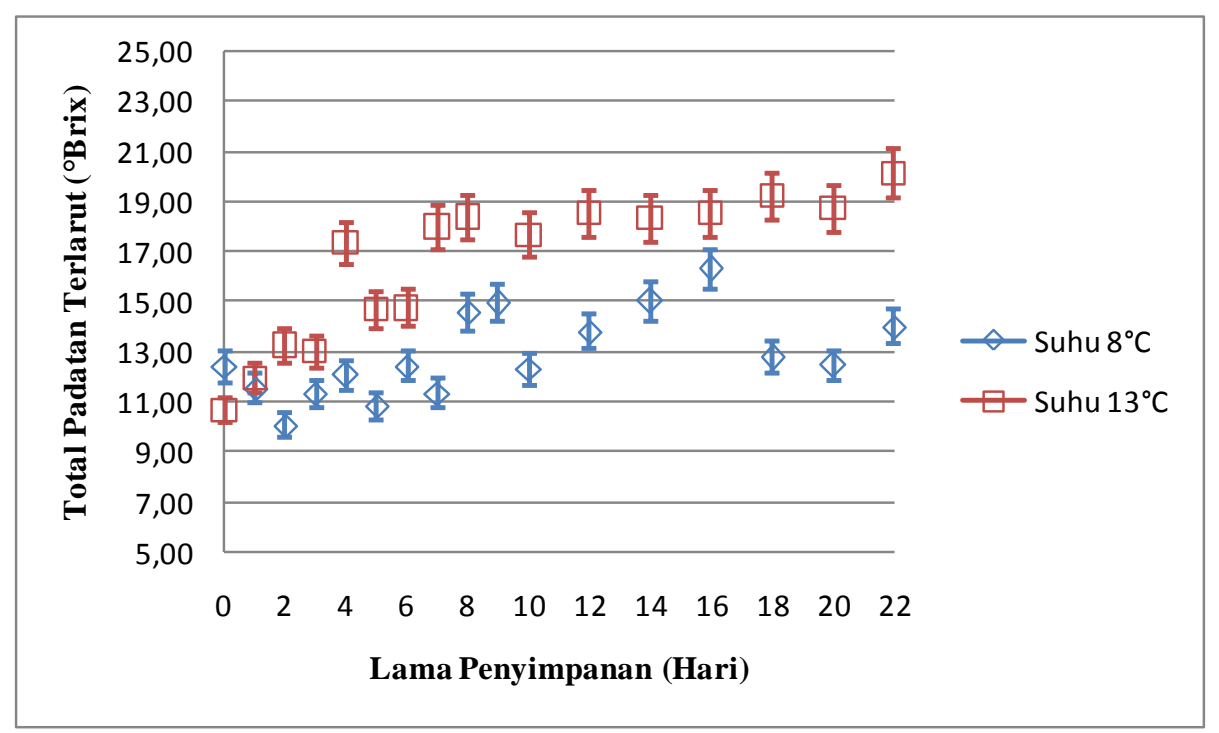

Gambar 2. Perubahan Total Padatan Terlarut Selama Penyimpanan Dingin

\section{Ion Leakage}

Laju perubahan ion leakage ini bersifat fluaktif dimana untuk penyimpanan buah mangga suhu $8{ }^{\circ} \mathrm{C}$ pada hari ke-4 laju perubahan ion meningkat dan turun pada hari ke-5 dan akhir penyimpanan (Tabel 1). Hal ini menunjukkan bahwa awal kebocoran ion terjadi pada hari ke-4 dan hari ke-6 dengan laju perubahan ion leakage sebesar 0.240 dan 0.257 diindikasikan sebagai awal terjadinya gejala chilling injury. Terjadinya kerusakan membran juga telah diamati oleh Naruke et al., dimana kerusakan ion leakage pada penyimpanan buah mentimun yang terjadi pada suhu penyimpanan $5^{\circ} \mathrm{C}$.

Tabel 1. Laju Perubahan Ion Leakage Pada Penyimpanan Suhu $8{ }^{\circ} \mathrm{C}$.

\begin{tabular}{cc}
\hline Hari penyimpanan & Laju ion leakage \\
\hline 1 & 0,182 \\
2 & 0,204 \\
3 & 0,236 \\
$\mathbf{4}^{*}$ & $\mathbf{0 , 2 4 0}$ \\
5 & 0,231 \\
\hline *Dugaan hari terjadinya gejala chilling injury secara destruktif
\end{tabular}

Gejala chiling injury yang dapat dilihat secara visual seperti bercak-bercak hitam atau kecoklatan dipermukaan, mulai muncul pada hari ke-10 untuk penyimpanan buah mangga suhu $8{ }^{\circ} \mathrm{C}$ dan semakin berkembang pada akhir penyimpanan dengan bintik-bintik hitam semakin berkembang dan munculnya browning pada bagian permukan buah mangga (Gambar 3). 


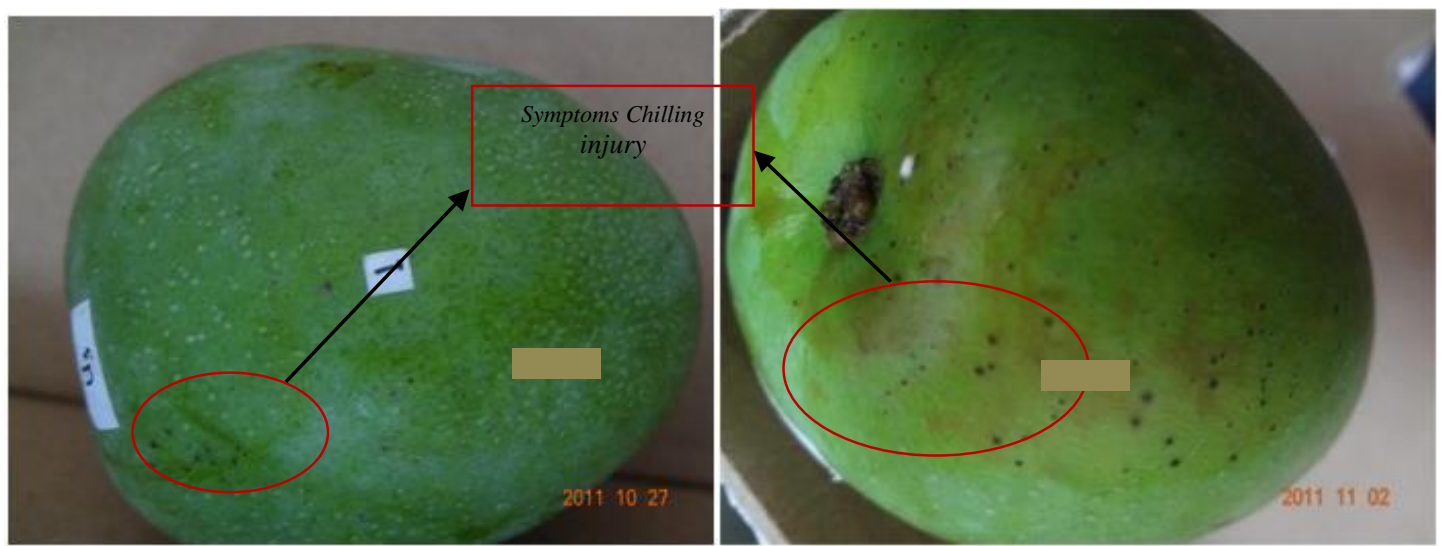

Gambar 3. Kondisi buah monitoring pada penyimpanan suhu $8^{\circ} \mathrm{C}$ sebagai gejala chilling injury (a) hari ke-10 bercak-bercak hitam, dan (b) hari ke-16 browning.

\section{Perubahan pH}

Perubahan $\mathrm{pH}$ pada buah mangga yang terjadi selama penyimpanan untuk suhu $8{ }^{\circ} \mathrm{C}$ tidak banyak meningkat dari penyimpanan hari ke-0 sampai hari ke-22 yaitu 3.02 menjadi 3.37. Sedangkan untuk penyimpanan suhu $13{ }^{\circ} \mathrm{C}$ mengalami peningkatan $\mathrm{pH}$ yang cukup tinggi yaitu 3.05 menjadi 4.69 (Gambar 4). Perubahan $\mathrm{pH}$ dapat dijadikan sebagai petunjuk terjadinya kerusakan dingin (Purwanto, et al., 2005). Dengan adanya indikasi $\mathrm{pH}$ ini dapat dinyatakan bahwa perubahan $\mathrm{pH}$ pada suhu rendah yang tidak normal dapat dijadikan sebagai indikasi gejala kerusakan dingin. Hal ini juga dapat dilihat dari analisis statistik bahwa suhu penyimpanan dan lama penyimpanan berpengaruh terhadap perubahan pH yaitu nilai signifikan kecil dari 0.05 (Tabel 2).

Tabel 2. Analysis of Variance (ANOVA)

\begin{tabular}{lccccc}
\hline \multicolumn{1}{c}{ Sumber } & Jumlah Kuadran & $\mathrm{db}$ & Kuadran Tengah & Fhitung & Sig. \\
\hline Suhu penyimpanan & 3,603 & 1 & 3,603 & 341,089 & $3,36 \times 10^{-28}$ \\
Lama penyimpanan & 6,571 & 16 & 0,411 & 38,878 & $6,75 \times 10^{-28}$ \\
Suhu penyimpanan * lama & 3,866 & 16 & 0,242 & 22,874 & $3,03 \times 10^{-21}$ \\
penyimpanan & & & & & \\
Galat & 0,718 & 68 & 0,011 & & \\
Total & 1201,028 & 102 & & & \\
\hline
\end{tabular}

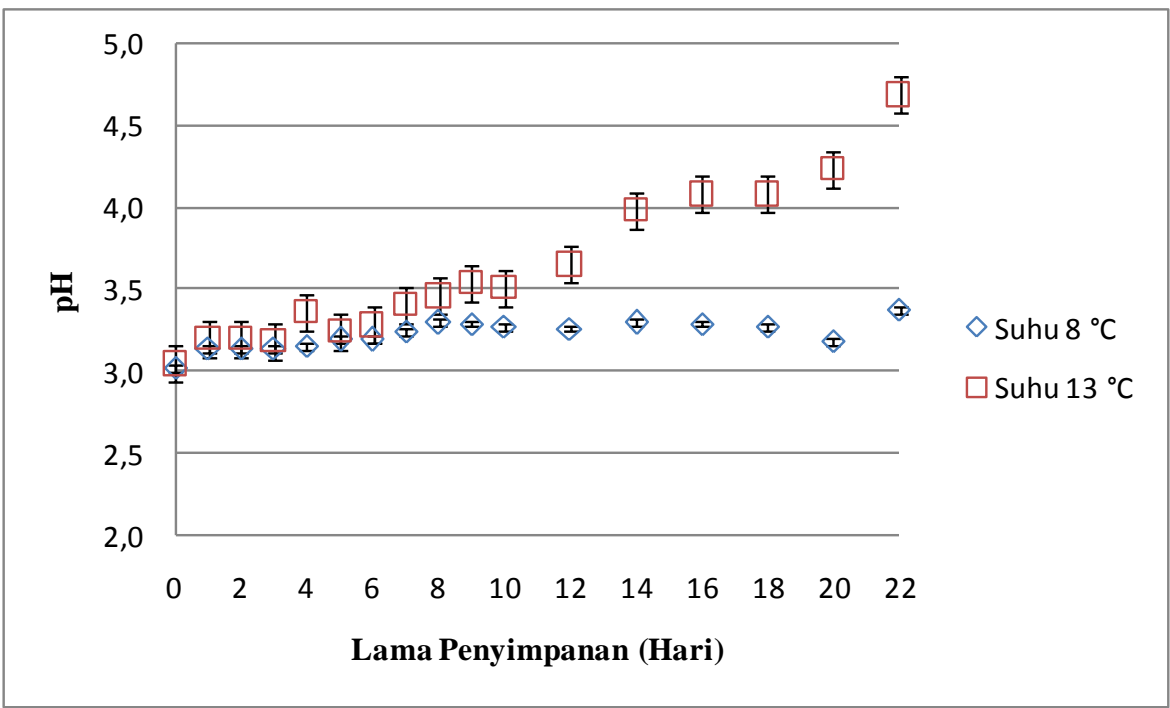

Gambar 4. Perubahan pH Selama Penyimpanan Dingin 


\section{KESIMPULAN}

Identifikasi gejala chlling injury dapat dilihat dari perubahan $\mathrm{pH}$ dan ion leakage buah mangga selama penyimpanan dingin. Hal ini dapat dilihat pada penelitian yaitu $\mathrm{pH}$ tidak mengalami peningkatan yang drastis pada penyimpanan suhu $8^{\circ} \mathrm{C}$. Dimana perubahan $\mathrm{pH}$ dari 3.02 menjadi 3.37. Dari salah satu gejala CI parameter $\mathrm{pH}$ tersebut, buah mangga telah mengalami gagal matang. Untuk parameter perubahan ion leakage yang terbesar untuk penyimpanan $8{ }^{\circ} \mathrm{C}$ terjadi pada hari penyimpanan ke-4 dan hari ke-6 untuk penyimpanan $13^{\circ} \mathrm{C}$.

\section{DAFTAR PUSTAKA}

Azvedo IG et al. 2008. P-type $H^{+}$-ATP Ases Activity, Membran Integrity, and Apoplastic pH During Papaya Fruit Ripening. Vol 48: 242-247.

Fahmy, K. dan Kohei Nakano. 2013. Influence of Relative Humidity on Development of Chilling Injury of Cucumber Fruits During Low Temperature Storage. Asia Pacific Journal of Sustainable Agriculture Food and Energy. Vol 1 . (1): 1-5

Muchtadi, T. R, Sugiyono, Ayustaningwarno, F. 2010. Ilmu Pengetahuan Bahan Pangan. Bandung: Alfabeta.

Naruke T, Oshita O, Kuroki S, Seo Y, and Kawagoe Y. 2003. T $_{1}$ Relaxation Time and Other Properties of Cucumber in Relation to Chilling Injury. Vol 599: 265-271. Acta Hort.

Oubahou, A. 1999. Characterization and Control of Chilling Injury of Some Horticultural Comodities. CIHEAM. Options Mediterraneennes. Page 115-123

Pantastico Er. B (Ed). 1989. Fisiologi Pasca Panen, Penanganan, dan Pemanfaatan Buah-buahan dan Sayur-sayuran Tropika dan Sub Tropika. Gadjah Mada University Press. Terjemahan dari: Kamariyani.

Paull, RE. 1980. Temperatur-Induced Leakage from Chilling Sensitif and Chilling Resistant Plants. Vol 68: 149-153. Plant Physiologi.

Purwanto, Y. A., S. Oshita, Y. Kawagoe and Y. Makino. 2005. Determination of Chilling Injury in Cucumber Fruits Through Proton NMR Analysis. Procedings reviewed paper International Conference on Research Highlights and Vanguard Technology on Environmental Engineering in Agricultural System, September 12-15, 2005, Kanazawa, Japan.

Purwanto et al. 2012. Indikasi Kerusakan Dingin pada Mentimun Jepang (Cucumis sativus L.) Berdasarkan Perubahan Ion Leakage dan pH. JTEP Jurnal Keteknikan Pertanian.

Pracaya. 2001. Bertanam Mangga. Jakarta. Penebar Swadaya.

Skog, L. J. 1998. Chilling Injury of horticultural Crops. Agdex: 736/202, Order: 98-021. Ministry of Agriculture, Food and rural Affairs.

Tasneem, Azra. 2004. Postharvest Treatments to Reduce Chilling Injury Symptoms in Storage Mangoes. Departement of Bioresources Engineering. McGill University. Canada.

Taub AI, and Sighn RP. 1998. Food Storage Stability. New York. CRC Press.

Utama, I. M. S. 2009. Stress pada Produk Pascapanen. Jurnal Postharvest Physiology. Hal: 1-15.

Salveit ME. 2002. The Rate of Ion Leakage from Chilling-Sensitif Tissue Doe Not Immediately Increase Upon Eexposure to Chilling Temperaturs. Vol 26: 295-304.

Sayyari, et al. 2011. Vapour Treatments with Methyl Salicylate or Methyl Jasmonate Alleviated Chilling Injury and Enhanced Antioxidant Potential during Postharvest Storage of Pomegranates. Food chemistry. Elsevier. Volume 124, issue 3.

Winarno, F. G. 2002. Fisiologi lepas panen produk hortikultura. Brios Press. Bogor. 